\title{
Role of the Physical Elicitors in Enhancing Postharvest Antioxidant Capacity of Table Grape $c v$ Redglobe (Vitis vinifera L.)
}

\author{
Pasquale Crupi ${ }^{1}$, Arianna Pichierri ${ }^{1}$, Rosa Anna Milella ${ }^{1}$, Rocco Perniola ${ }^{1}$ \& Donato Antonacci ${ }^{1}$ \\ ${ }^{1}$ CRA - Consiglio per la Ricerca e la sperimentazione in Agricoltura - Unità di ricerca per l'uva da tavola e la \\ vitivinicoltura in ambiente mediterraneo, Italy \\ Correspondence: Donato Antonacci, CRA - Consiglio per la Ricerca e la sperimentazione in Agricoltura - Unità \\ di ricerca per l'uva da tavola e la vitivinicoltura in ambiente mediterraneo, Italy. Tel: 39-080-891-5711. E-mail: \\ donato.antonacci@entecra.it
}

Received: October 28, 2013 Accepted: February 10, 2014 Online Published: February 17, 2014

doi:10.5539/jfr.v3n2p61

URL: http://dx.doi.org/10.5539/jfr.v3n2p61

\begin{abstract}
Polyphenols, such as anthocyanins, are secondary metabolites produced in plants which can play an important health-promoting role considering their strong correlation with antioxidant capacity. The biosynthesis of these compounds generally increases as a response to biotic or abiotic stress, therefore, in order to achieve as high phenolic accumulation as possible, the interactive effects of storage conditions (temperature and time) and postharvest ultraviolet irradiation (UV-C) on total polyphenols (TPP) and total anthocyanins (TA) content, as well as oxygen radical antioxidant capacity (ORAC), in postharvest "Redglobe" table grape variety were investigated in 2011 vintage. Gathered findings showed that UV-C exposure ranging from 1 to $3 \mathrm{~min}(0.8-2.4 \mathrm{KJ}$ $\mathrm{m}^{-2}$ ) positively influence the TA level (with an increase almost twice higher than the control) during a storage time longer than $48 \mathrm{~h}$, independently from the storage temperature; while, with regard to TPP and ORAC, a progressive increment of their values (roughly from 2 to 4 folds higher than the control) up to $120 \mathrm{~h}$ of storage was observed, in particular in Redglobe grapes irradiated for $1 \mathrm{~min}$ and stored at $4{ }^{\circ} \mathrm{C}$. Responding to the rising consumers needs to have foods that support and promote health, this research demonstrated that the postharvest simultaneous application of physical elicitors can lead to grapes with enhanced antioxidant properties, within normal conditions of market commercialization. The practical relevance of this finding is evident considering that grapes are economically the most important fruit species in the world and approximately $30 \%$ of its production is used as fresh fruit.
\end{abstract}

Keywords: physical elicitors, UV-C, polyphenols, anthocyanins, ORAC

\section{Introduction}

The grape consumption has been associated with multiple beneficial health effects mainly due to the polyphenol content in this fruit (Cook \& Samman, 1996; Teissendre et al., 1996). Phenolics are secondary metabolites that are widely distributed in the plant kingdom. Typically in Vitis vinifera they are present as flavonoids, comprising flavanols, anthocyanins and flavan-3-ols, and non-flavonoids, comprising hydroxybenzoic acids, hydroxycinnamic acids and stilbenes (Glories, 1998). Numerous studies have established that total anthocyanins as well as phenolic concentrations are positively related to the total antioxidant activity (Wang, Cao, \& Prior, 1997; Meyers, Watkins, Pritts, \& Liu, 2003; Sun, Chu, Wu, \& Liu, 2002).

Recently, due to health awareness campaigns, consumers have become more and more interested in foods that support and promote health which are characterized by high health-promoting compound content rather than having superior external quality attributes, as was previously the case. Therefore, to meet this shift in consumer needs the use of postharvest elicitors, that can promote the levels of phytochemicals in postharvest crops, has become an area of key interest (Goldmann, Kader, \& Heintz, 1999; Huyskens-Keil \& Schreiner, 2004).

It is known that quantitative and qualitative pattern of polyphenols depends on the developing stage of a plant, which means that by selecting the harvest time it is possible to obtain products with different flavonoid profiles. Generally, in order to improve the elicitor's effect on the accumulation of phenols during the postharvest stage, fruit and vegetables should be harvested at optimum maturity (Schreiner \& Huyskens-Keil, 2006; Terry \& Joyce, 2004). The storage process can modify the content of phenolic acids and flavonoids in the plant material, leading to an increase or decrease which depend on the storage conditions, such as temperature and time, but also 
phytochemical stability, and quality of the analyzed food. Generally, a decrease in the polyphenol content with high temperature was shown, but, in other cases, fruit stored at higher temperature has shown higher anthocyanin and flavonoid concentrations and higher antioxidant activity than at lower temperature (Amarowicz et al., 2009; Kalt, Forney, Martin, \& Prior, 1999; Shin, Liu, Nock, Holliday, \& Watkins, 2007).

Ultraviolet irradiation (UV-C) acts as an abiotic physical elicitor of resistance mechanisms, and thus leads to a rapid increment of stress-response compounds such as phenols, flavonoids, and phytoalexins, due to the increased activity of phenylalanine ammonia-lyase and other enzymes involved in flavonoid synthesis (Tomas-Barberan \& Espin, 2001). This effect was found in several fruits, such as citrus (Oufedjikh, Mahrouz, Amiot, \& Lacroix, 2000), apples (Dong, Mitra, Kootstra, Lister, \& Lancaster, 1995), peas (Plustoka, Michalczyk, \& Gorecki, 2005), and grapes (Takayanagi, Okuda, Mine, \& Yokotsuka, 2004). UV-C of fruit and vegetables as a postharvest treatment has been shown to improve quality throughout storage, e.g. by increasing anthocyanin levels in strawberries; moreover, a recent study has also demonstrated that postharvest application of UV-C is effective in stimulating the antioxidant capacity of some fruit (Wang, Cao, \& Prior, 2009; Alothman, Bhat, \& Karim, 2009).

However, to the best of our knowledge, few researchers have studied the simultaneous influence of physical postharvest treatments on antioxidant activity in grapes ( $\mathrm{Li}$ et al., 2009); therefore, the aim of this work was to evaluate the interactive effects of UV-C and storage conditions (time and temperature) on the antioxidant capacity, expressed as total polyphenols (TPP) and ORAC values, together with total anthocyanins (TA) concentration in Redglobe table grape variety from 2011 vintage, in order to monitor its health and nutritional aspects during current conditions of market commercialization (short term and cold storage).

\section{Materials and Methods}

\subsection{Plant Material and Growth Conditions}

The experiment was conducted in 2011 on the table grape variety "Redglobe" (Vitis vinifera L.) grown in Apulian region. The vineyard was located in a trial site on a hilly area (in Turi, Southern Italy, long. $40.56^{\circ} \mathrm{E}$, lat $17.12^{\circ} \mathrm{N}$ ) at about $250 \mathrm{~m}$ on the sea level and planted in a sandy-clay soil composed of $50 \%$ sand, $12 \%$ slit and $38 \%$ clay, with a root zone depth of $1 \mathrm{~m}$. All vines were established in 2004 on 140 Ruggeri (Vitis berlandieri $x$ Vitis rupestris) rootstocks, with a planting density of 1600 vines ha $^{-1}$, and a vine spacing of $2.5 \mathrm{~m}$ between rows and $2.5 \mathrm{~m}$ within a row. They were trained to a "double tendon" trellis system, widely used in Apulian region, and were cane pruned (two canes every 12-15 buds per vines) with free-standing shoots (complete overhead canopy separated from fruit). Improving the canopy management, the "double tendon" assured optimal microclimate conditions for bunches and avoided the leaves to rub them, during very windily days. Grape samples (10 bunches by taking a bunch for each vine, in the middle of the fruit cane) were harvested at commercial maturity on the basis of total soluble solids (TSS), measured as ${ }^{\circ}$ Brix using a portable refractometer (Atago PR32, Norfolk, Virginia, USA), and titratable acidity which was determined in the juice by titration with $0.1 \mathrm{~N}$ of $\mathrm{NaOH}$ (J.T. Baker, Deventer, Holland) to a $\mathrm{pH} 7$ end point, and was expressed as gram of tartaric acid per liter.

\subsection{Experimental Design of the Postharvest Treatments}

Berries of set weight $(10 \pm 1 \mathrm{~g})$ were detached from bunches and mixed to obtain a homogeneous and representative sample. Three replicates of 10 berries samples were weighted and treated with a full factorial experimental design, as described in Table S1 (Supporting Information), with a sample size of $2 \times 4 \times 4=32$ unique runs, given by the product among the levels of the factors,. Germicidal UV-C lamp (SANKYO DENKI G30T8 - Levanchimica s.r.l. Bari - Italy) has been used as UV-C source with peak emission at $254 \mathrm{~nm}$ and $893 \mathrm{x}$ $25.5 \mathrm{~mm}$ dimensions. The UV-C light intensity was kept constant $(13.4 \mathrm{~W})$ and the applied doses $(0.8,2.4$, and $4.1 \mathrm{KJ} \mathrm{m}^{-2}$, respectively) varied by altering the exposure time $(1,3$, and $5 \mathrm{~min})$ at the fixed distance of $40 \mathrm{~cm}$ (López-Rubira, Conesa, Allende, \& Artés, 2005) from the berries. The 10 berries have been irradiated only on a side.

Each sample was stored (for a time of 24,48 , and $120 \mathrm{~h}$ ) at either room temperature $\left(25^{\circ} \mathrm{C}\right)$ or $4{ }^{\circ} \mathrm{C}$ in perforated plastic bags and at relative humidity of $90-95 \%$ to avoid water loss and shriveling. Finally, the treated grape samples were immediately frozen at $-20^{\circ} \mathrm{C}$ for later analyses.

\subsection{Extraction and Analysis of Total Polyphenols and Anthocyanins}

The frozen 10-berries samples were manually separated from pulp and freeze-dried skin samples were homogenized by an IKA A11 basic homogenizer (IKA Works, NC, USA). The homogenate was transferred to a volumetric flask and extracted using $25 \mathrm{~mL}$ of $70 \%$ ethanol (J.T. Baker, Deventer, Holland) solution, containing 
$1 \%$ hydrochloric acid (J.T. Baker, Deventer, Holland). The mixture was sonicated for 5 min at $20{ }^{\circ} \mathrm{C}$ and then centrifuged $(4000 \mathrm{rpm} ; 3 \mathrm{~min})$. This procedure was repeated three times and the effectiveness of repetitive extraction was tested by measuring the absorbance at $520 \mathrm{~nm}$. The third extraction represented less than $1 \%$ of the compounds that were extracted. Then three supernatants were combined and filtered through a $0.45 \mu \mathrm{m}$ syringe cellulose filter (VWR International, USA), after which the absorbance of the extract as such, and of diluted extract (1:50) using Folin-Ciocalteau method (as fully described in Milella et al., 2012), was determined at $520 \mathrm{~nm}$ and $750 \mathrm{~nm}$, respectively, by means of a FLUOstar OPTIMA (BMG LABTECH, Offenburg, Germany) plate reader. From these values, total anthocyanins (TA) and total polyphenols (TPP) were calculated by using calibration curves of malvidin-3O-glucoside (at concentrations $0.1-50 \mathrm{mg} \mathrm{L}^{-1} ; \mathrm{R}^{2}=0.9908$ ) and catechin (at concentrations $1-100 \mathrm{mg} \mathrm{L}^{-1} ; \mathrm{R}^{2}=0.9912$ ), respectively (Extrasynthese - Genay, France). Finally, they were expressed in mg equivalents per $\mathrm{Kg}$ of berry fresh weight (fw).

\subsection{Oxygen Radical Absorbance Capacity Assay (ORAC)}

This fluorimetric procedure is based on a previously reported method (Ou, Hampsch-Woodill, \& Prior, 2001) with slight modifications. Briefly, $25 \mu \mathrm{L}$ of diluted sample (1: 500), blank, or Trolox calibration solution $(6.25-100 \mu \mathrm{M})$ were mixed with $150 \mu \mathrm{L}$ of fluorescein $(7.7 \mu \mathrm{M})$ and incubated for 15 min at $37^{\circ} \mathrm{C}$ before injection of $25 \mu \mathrm{L}$ AAPH (2,2'-azobis[2-methylpropionamide]dihydrochloride, Sigma-Aldrich, Milano, Italy) solution $(221.3 \mathrm{mM})$. The fluorescence was measured at $\lambda_{\text {exc }}=485 \mathrm{~nm}$ and $\lambda_{\text {ems }}=535 \mathrm{~nm}$ every $90 \mathrm{sec}$ for 60 min, using a FLUOstar OPTIMA (BMG LABTECH, Offenburg, Germany) plate reader. All samples were analyzed in duplicate. The final ORAC values were calculated using the differences of the area under the fluorescence decay curve (AUC) between the blank and the sample, and were expressed as $\mu$ mol of Trolox Equivalents (TE) per Kg of berry fresh weight (fw).

\subsection{Statistical Analyses}

The data were statistically analyzed by means of STATISTICA 8.0 software package (StatSoft Inc., Tulxa, OK), using the General Regression Model (GRM) module in order to analyze an ANOVA design with categorical predictor variables. Three factorial analysis of variance (ANOVA) were applied to TPP, TA, and ORAC data of 2011 samples, and the significance of single factors and interactions of them were determined at $\mathrm{P}<0.05, \mathrm{P}<$ 0.01 , or $\mathrm{P}<0.001$; moreover, the optimizazion of the experimental conditions was evaluated using a response surface methodology (RSM). The proposed model to which the experimental data were fitted was a second-order polynomial model. The following equation was used:

$$
\mathrm{Y}=\mathrm{a}_{0}+\mathrm{a}_{1} \mathrm{X}_{1}+\mathrm{a}_{2} \mathrm{X}_{2}+\mathrm{a}_{3} \mathrm{X}_{3}+\mathrm{a}_{12} \mathrm{X}_{1} \mathrm{X}_{2}+\mathrm{a}_{13} \mathrm{X}_{1} \mathrm{X}_{3}+\mathrm{a}_{23} \mathrm{X}_{2} \mathrm{X}_{3}+\mathrm{a}_{11} \mathrm{X}_{1}{ }^{2}+\mathrm{a}_{22} \mathrm{X}_{2}{ }^{2}+\mathrm{a}_{33} \mathrm{X}_{2}^{2}
$$

where $\mathrm{Y}$ is the amount $(\mathrm{mg})$ of extracted compounds per $\mathrm{Kg}$ of fresh weight of grapes and is normalized to control samples, $\mathrm{a}_{\mathrm{i}}$ are the regression coefficients, and $\mathrm{X}_{1}, \mathrm{X}_{2}$, and $\mathrm{X}_{3}$ are the experimental factors.

\section{Results and Discussion}

According to previously reported data for Redglobe variety (Morelli et al., 2008), berries of uniform size and weight were chosen in order to prevent their dimension variability could affect the experimental results. Moreover, on the basis of TSS and titratable acidity values $\left(15^{\circ}\right.$ Brix and $4.13 \mathrm{~g} \mathrm{~L}^{-1}, 17.2^{\circ}$ Brix and $4.65 \mathrm{~g} \mathrm{~L}^{-1}$, measured in 2011 and 2012 vintages, respectively) the optimal harvest time was chosen to allow postharvest physical elicitors to get the best activity on the phytochemicals improvement. Indeed, color development during postharvest ripening is significantly affected by the initial pigment content and even fruits harvested at commercial maturity may exhibit increases in the anthocyanin content throughout cold-temperature storage (Schreiner \& Huyskens-Keil, 2006; Nunes, Brecht, Morais, \& Sargent, 2006).

Table 1 lists the values of postharvest TPP and TA content, together with ORAC values in the skin extracts of Reglobe grapes (Vitis vinifera L.) harvested in 2011 vintage, as affected by storage conditions and UV-C treatment. Highly significant interaction among storage temperature and time, and UV-C treatment were found, a general increment with dose irradiation and storage conditions was observed, in particular higher values of TPP and ORAC were obtained at $4{ }^{\circ} \mathrm{C}$, after $120 \mathrm{~h}$ (roughly $400 \mathrm{mg} \mathrm{Kg}^{-1}$ and $27000 \mu \mathrm{mol} \mathrm{TE} \mathrm{Kg}^{-1}$ of fw, respectively) and $1 \mathrm{~min}$ of UV-C exposure, whilst for TA the better increase (up to $126 \mathrm{mg} \mathrm{Kg}^{-1}$ of fw) was detected after $48 \mathrm{~h}$ and between 1 and $3 \mathrm{~min}$ of UV-C irradiation. Moreover, it is worth noting that any irradiated samples did not improve their anthocyans level compared to control after storing for less than $48 \mathrm{~h}$ both at room temperature or $4{ }^{\circ} \mathrm{C}$; conversely, they needed at least $120 \mathrm{~h}$ of storage to significantly increase their polyphenolic content as well as ORAC values (Table 1).

The storage time factor had a very significant $(\mathrm{P}<0.001)$ impact on each examined parameter. TPP were significantly increased just after $24 \mathrm{~h}$ of storage changing from an average of $265 \mathrm{mg} \mathrm{Kg}^{-1}$, at harvest, to $319 \mathrm{mg}$ 
$\mathrm{Kg}^{-1}$ of fw with an increment of $18 \%$ compared to control sample, moreover a further increase of TPP up to an average of $374 \mathrm{mg} \mathrm{Kg}^{-1}$ was observed in Redglobe samples after $120 \mathrm{~h}$ of storage (Figure 1a). A similar trend was depicted by ORAC values, too: two consecutive increases after 24 and $120 \mathrm{~h}$ (from an average of 6500 to 10600 and $16600 \mu \mathrm{mol} \mathrm{TE} \mathrm{Kg}{ }^{-1}$, respectively) were observed (Figure 1c). This can be ascribed to the positive relationship ( $\mathrm{r}=0.65, \mathrm{p}<0.05 ; \mathrm{N}=32)$ mainly between TPP and antioxidant capacity, that is in line with previously reported data (Meyers et al., 2003; Sun et al., 2002). Also TA level was positively affected by storage time, showing a large increase after $48 \mathrm{~h}$ with a value $\left(106 \mathrm{mg} \mathrm{Kg}^{-1}\right.$ of fw) almost twice higher than the harvest one; in this case, however, no further increment was observed after $120 \mathrm{~h}$ of storage (Figure 1b). On the contrary, temperature has no significant effect on the TA level of the stored Redglobe grapes (Table 1). Considering that higher temperatures should enhance anthocyanin biosynthesis during storage, this finding seems in disagreement with some of literature data (Goncalves, Landbo, Knudsen, \& Silva, 2004). Indeed berries, such as strawberries, blueberries, and raspberries, stored at temperatures $>15{ }^{\circ} \mathrm{C}$ show higher anthocyanins and phenolics contents compared to those stored at lower ones $\left(0\right.$ to $\left.6{ }^{\circ} \mathrm{C}\right)$ (Kalt et al., 1999; Cordenunsi et al., 2005). However, other studies have demonstrated that cold storage for up to 3 days leads to relatively small changes in the concentration of different antioxidants in strawberries (Olsson, Ekvall, Gustavsson, \& Nilsson, 2004), and that the anthocyanin content of raspberries is not affected by 3 days freezing at $4^{\circ} \mathrm{C}$ (Amarowicz et al., 2009).
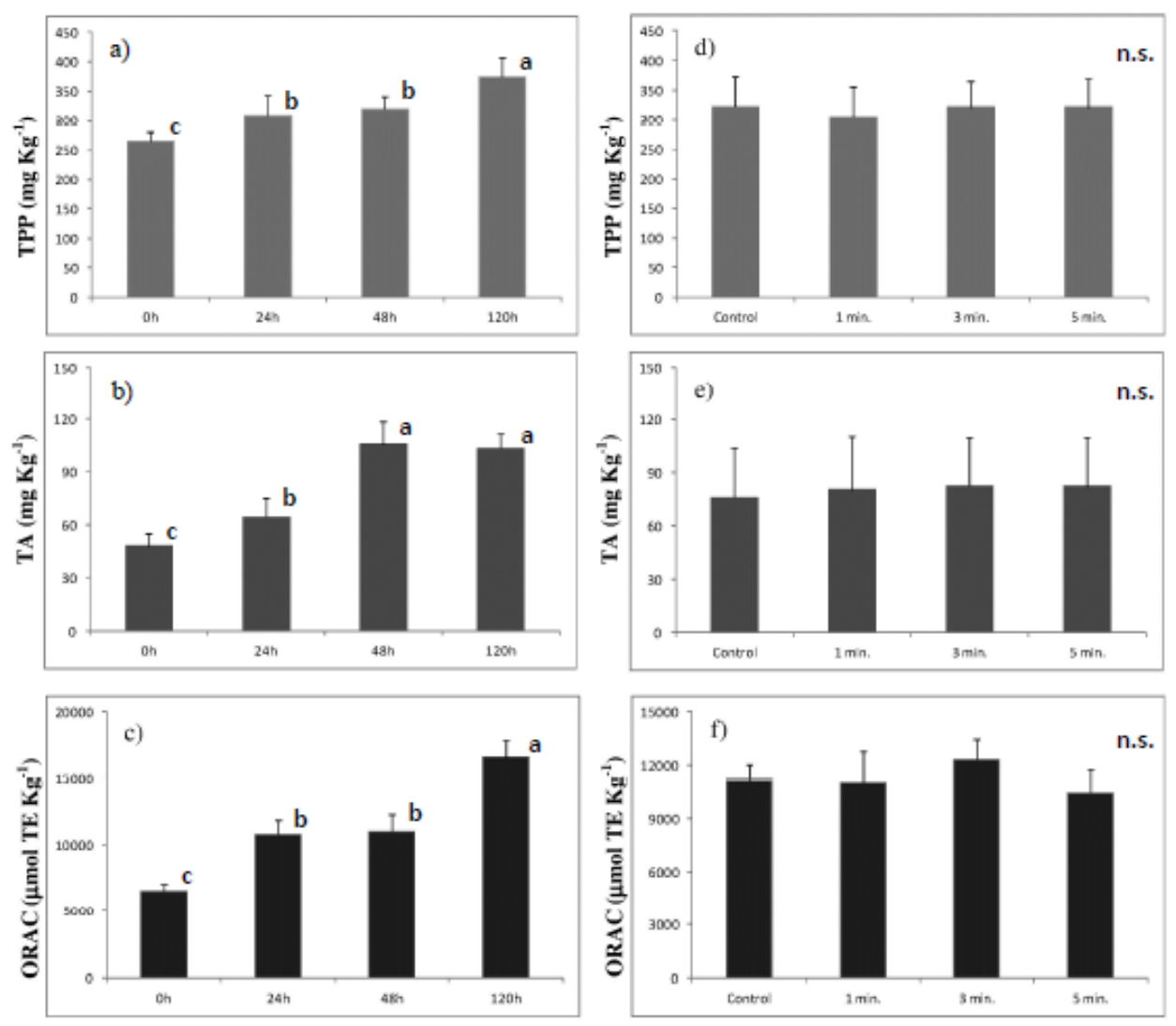

Figure 1. Effects of storage time (a-b-c) and UV-C treatment (d-e-f) on total polyphenols (TPP), anthocyanins (TA), and oxygen radical absorbance capacity (ORAC) values in the skin extracts of Redglobe (Vitis vinifera $\mathrm{L}$.). Different letters indicate statistical significance according to Tuckey's HSD post hoc test. n.s. $=$ not significant 
Table 1. Effect of storage time, storage temperature, and UV-C treatment on the total polyphenols (TPP), total anthocyanins (TA), and oxygen radical antioxidant capacity (ORAC) postharvest values in the skin extracts of Redglobe table grape (Vitis vinifera $\mathrm{L}$.) harvested in 2011

\begin{tabular}{|c|c|c|c|c|c|}
\hline $\begin{array}{c}\text { UV-C } \\
\text { treatment }\end{array}$ & $\begin{array}{c}\text { Storage } \\
\text { Time }\end{array}$ & $\begin{array}{c}\text { Storage } \\
\text { Temperature }\end{array}$ & TPP $\left(\mathrm{mg} \mathrm{Kg}^{-1}\right)$ & TA $\left(m g ~ K g^{-1}\right)$ & ORAC $\left(\mu \mathrm{mol} \mathrm{TE} \mathrm{Kg}^{-1}\right)$ \\
\hline \multirow{8}{*}{ Coltrol } & \multirow{2}{*}{$0 \mathrm{~h}$} & $\mathrm{RT}^{a}$ & $272^{b}$ & 40.3 & 10170 \\
\hline & & $\mathrm{CS}$ & 278 & 42.9 & 10166 \\
\hline & \multirow{2}{*}{$24 \mathrm{~h}$} & RT & 282 & 49.4 & 4829 \\
\hline & & $\mathrm{CS}$ & 376 & 86.9 & 10238 \\
\hline & \multirow{2}{*}{$48 \mathrm{~h}$} & RT & 301 & 110.5 & 11813 \\
\hline & & $\mathrm{CS}$ & 294 & 78.9 & 9008 \\
\hline & \multirow{2}{*}{$120 \mathrm{~h}$} & RT & 366 & 106.5 & 11768 \\
\hline & & $\mathrm{CS}$ & 401 & 92 & 21134 \\
\hline \multirow{8}{*}{$1 \mathrm{~min}$} & \multirow{2}{*}{$0 \mathrm{~h}$} & RT & 243 & 45.7 & 4813 \\
\hline & & $\mathrm{CS}$ & 256 & 41 & 5286 \\
\hline & \multirow{2}{*}{$24 \mathrm{~h}$} & RT & 290 & 64.7 & 7165 \\
\hline & & $\mathrm{CS}$ & 290 & 64.5 & 20466 \\
\hline & \multirow{2}{*}{$48 \mathrm{~h}$} & RT & 339 & 104 & 3565 \\
\hline & & $\mathrm{CS}$ & 296 & 110.5 & 13063 \\
\hline & \multirow{2}{*}{$120 \mathrm{~h}$} & RT & 318 & 99.6 & 6734 \\
\hline & & $\mathrm{CS}$ & 405 & 115.6 & 27182 \\
\hline \multirow{8}{*}{$3 \min$} & \multirow{2}{*}{$0 \mathrm{~h}$} & RT & 282 & 56.9 & 7875 \\
\hline & & $\mathrm{CS}$ & 284 & 59.2 & 6756 \\
\hline & \multirow{2}{*}{$24 \mathrm{~h}$} & RT & 316 & 60.7 & 6667 \\
\hline & & $\mathrm{CS}$ & 267 & 56.9 & 15549 \\
\hline & \multirow{2}{*}{$48 \mathrm{~h}$} & RT & 336 & 105.8 & 8568 \\
\hline & & $\mathrm{CS}$ & 350 & 126.2 & 20070 \\
\hline & \multirow{2}{*}{$120 \mathrm{~h}$} & RT & 333 & 93.2 & 13388 \\
\hline & & $\mathrm{CS}$ & 400 & 102.2 & 19827 \\
\hline \multirow{9}{*}{$5 \mathrm{~min}$} & \multirow{2}{*}{$0 \mathrm{~h}$} & RT & 253 & 49.7 & 3731 \\
\hline & & $\mathrm{CS}$ & 257 & 49.4 & 3572 \\
\hline & \multirow{2}{*}{$24 \mathrm{~h}$} & RT & 325 & 62.1 & 8299 \\
\hline & & $\mathrm{CS}$ & 321 & 71.4 & 13199 \\
\hline & \multirow{2}{*}{$48 \mathrm{~h}$} & RT & 308 & 107.2 & 3571 \\
\hline & & $\mathrm{CS}$ & 332 & 103 & 18538 \\
\hline & \multirow{3}{*}{$120 \mathrm{~h}$} & RT & 390 & 104.7 & 14070 \\
\hline & & $\mathrm{CS}$ & 378 & 113.1 & 18720 \\
\hline & & & \multicolumn{3}{|c|}{ Significance } \\
\hline \multicolumn{3}{|c|}{ UV C treatment (min) } & n.s. & n.s. & n.s. \\
\hline \multicolumn{3}{|c|}{ Storage time $(h)$} & $* * *$ & $* * *$ & $* * *$ \\
\hline \multicolumn{3}{|c|}{ Storage temperature $\left({ }^{\circ} \mathrm{C}\right)$} & $*$ & n.s. & $* * *$ \\
\hline \multicolumn{3}{|c|}{ Storage time $x$ Storage temperature } & $*$ & n.s. & $* * *$ \\
\hline \multicolumn{3}{|c|}{ Storage time $x U V C$ treatment } & n.s. & $* *$ & $* * *$ \\
\hline Storage tem & rature $x U I$ & C treatment & n.s. & n.s. & $* * *$ \\
\hline Storage tim & Storage te & tp. $x$ UV C treat & $* *$ & $* * *$ & $* * *$ \\
\hline
\end{tabular}

${ }^{a} \mathrm{RT}=$ room temperature, $\mathrm{CS}=$ cold storage $\left(4{ }^{\circ} \mathrm{C}\right) ;{ }^{b}$ Means of three replicates. Three-way ANOVA based on F-test was performed to obtain significance of treatments and interactions; $\mathrm{n} . \mathrm{s} .=$ not significant; $*=\mathrm{P}<0.05 ; * *$ $=\mathrm{P}<0.01 ; * * *=\mathrm{P}<0.001$ 
The similar response of TA, irrespective to the tested temperature storage condition (room temperature and $4{ }^{\circ} \mathrm{C}$ ), could be due to the typical lesser amount and non-homogeneous distribution of anthocyanin pigments on the skin of red grapes (such as Redglobe or Crimson) (Crupi et al., 2012), that would favor the further cellular biosynthesis of these compounds during postharvest storage. However more deepened molecular studies are in progress in our laboratories to support this hypothesis.

Irradiation of fruit and vegetables as a postharvest treatment has also been shown to improve antioxidant compounds throughout storage, such as in the case of citrus (Oufedjikh et al., 2000), apples (Dong et al., 1995), and peas (Plustoka et al., 2005), but in this research no significant effect was observed for UV-C dose treatment by itself (Table 1). Indeed, TA level slightly increased just after $1 \mathrm{~min}$ of treatment and further exposure of grapes to UV-C seem unnecessary to improve the content of these pigments (Figure 1e); conversely, TPP content, as well as ORAC values, did not change according to UV treatment if compared to control, but straight they slightly decreased after $1 \mathrm{~min}$ of berries exposure (Figures $1 \mathrm{~d}$ and f).

Response surface regression analyses were employed to predict the optimal improvement conditions on TPP, TA, and ORAC levels of Redglobe grapes during postharvest. Of course, in order to generalize the 2011 results, because polyphenols of a grape variety are mainly affected by the environmental conditions (Crupi et al., 2012), the data of Table 1 were first normalized to the control sample values and then fitted by a polynomial mathematical model to generate three-dimensional response surface plots with one constant factor (storage temperature) (Figure 2).
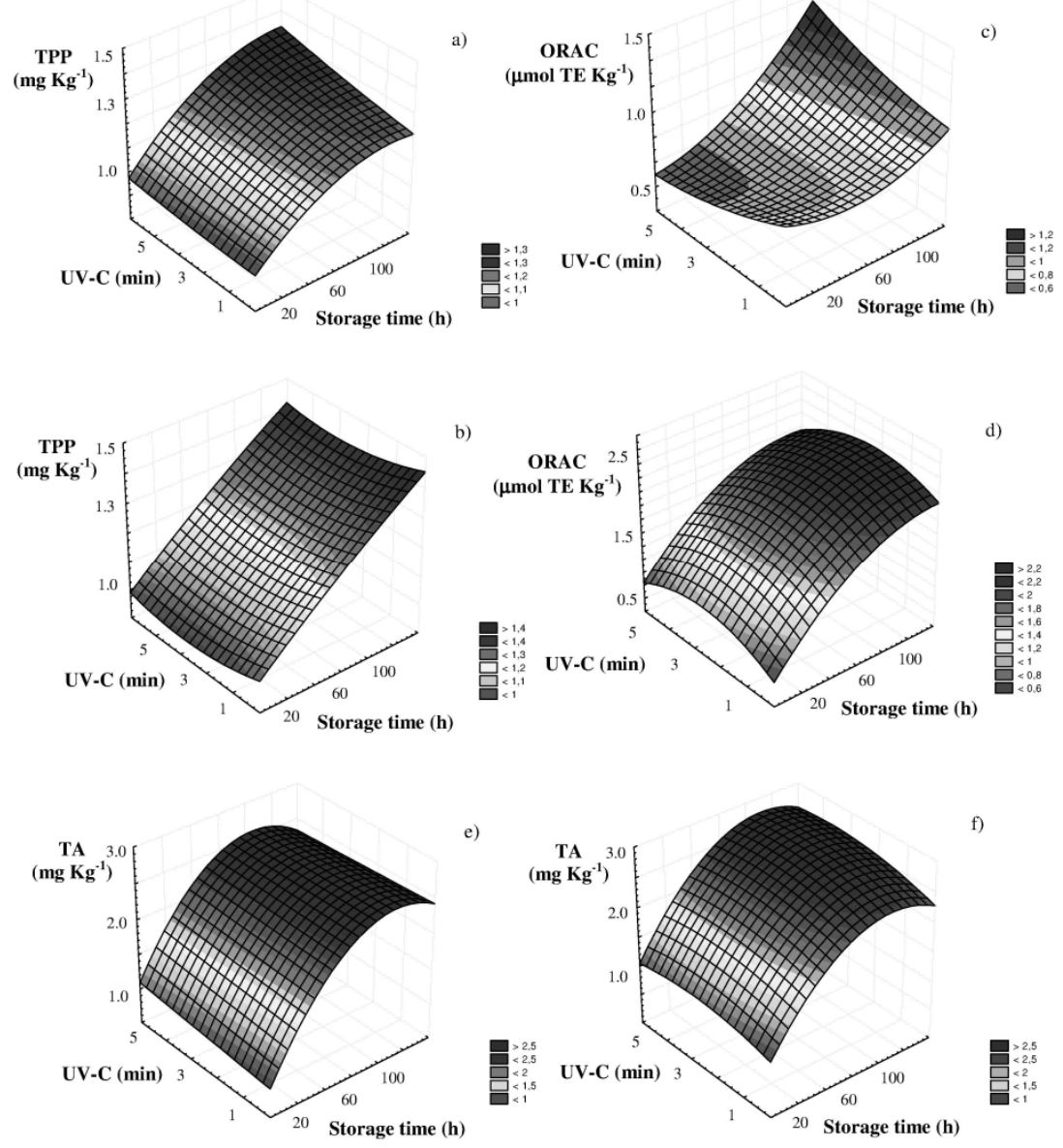

Figure 2. Response surface curves for total polyphenols (TPP), total anthocyanins (TA), and oxygen radical absorbance capacity (ORAC) variation depending on UV-C exposure and storage time effects at room temperature (a, c and e) and $4{ }^{\circ} \mathrm{C}(\mathrm{b}, \mathrm{d}$ and f) 
With regard to polyphenols and antioxidant activity changing (Adj $\mathrm{R}^{2}=0.54$ and 0.58 , respectively), variation of storage time $\left(\mathrm{a}_{2}\right)$ confirmed to exert the most significant effect of all the studied predictor variables (Table S2, Supporting Information). As can be seen in Figure 2, TPP and ORAC increased with longer storage time up to $120 \mathrm{~h}$. Moreover, a slight increase of total TPP level and antioxidant capacity was also observed storing samples at lower temperature $\left(4^{\circ} \mathrm{C}\right)$, as a consequence of positive interactions between storage time and temperature $\left(\mathrm{a}_{23}\right.$; see Table S2), while no significant influence of UV-C factor was noted on both parameters $\left(a_{12}\right.$ and $a_{13}$; see Table $\mathrm{S} 2$ ). In the case of anthocyanins (Adj $\left.\mathrm{R}^{2}=0.72\right)$, first, the significant quadratic terms $\left(\mathrm{a}_{11}\right.$ and $\left.\mathrm{a}_{22}\right)$ being negative means that a maximum increment of these compounds can be found in the considered experimental domain (Table S2, Supporting Information); TA variation in Redglobe during postharvest was primarily affected by the storage time and, to a lesser extent, by the UV-C dose exposure, while no significant impact of the storage temperature, in the considered range, was observed (Figure 2e and f). More precisely, better conditions to improve anthocyanins content were represented by a storage time between 48 and $60 \mathrm{~h}$ and UV-C treatment of almost 1 min.

This might be ascribed to the differing effects of low and high UV-C doses on the rate of phenylalanine ammonia-lyase (PAL) expression (Pan, Vicente, Martinez, Chaves, \& Civello, 2004). The biosynthesis of phenolic compounds is affected by gamma and ultraviolet irradiation due to the increased activity of PAL as well as other enzymes involved in flavonoid synthesis (Tomas-Barberan \& Espin, 2001) which can promote the accumulation of phenolic compounds, such as resveratrol in grapes (Takayanagi, Okuda, Mine, \& Yokotsuka, 2004) or anthocyanins in peach (Kataoka \& Beppu, 2004). Moreover, considering that low temperature storage has been shown to enhance postharvest phenolic metabolism in a wide variety of plant matrices (Lattanzio, 2003), even though in our case temperature factor was not relevant for phenolic improvement in postharvest grapes, it is worth noting that an UV-C exposure of berries for $1 \mathrm{~min}$ would seem sufficient to stimulate the anthocyanin biosynthesis also at room temperature.

\section{Conclusions}

To date, the effectiveness of postharvest treatments has been assessed mainly by the quality maintenance of harvested fruit and vegetables. However, with rising consumer interest in foods that promote health, attention has shifted from quality maintenance to quality assurance with particular emphasis on the enhancement of health-promoting phytochemicals. Therefore, to obtain fruit and vegetables enriched with phytochemicals, postharvest elicitor treatments might be used either singularly or in combination to obtain the desired effect. In this research interactive effect among UV-C treatment and storage conditions (time and temperature) on phenolic compounds in postharvest Redglobe table grape variety were determined. Irrespective to storage temperature, UV-C exposure ranging from 1 to $3 \mathrm{~min}\left(0.8-2.4 \mathrm{KJ} \mathrm{m}^{-2}\right)$ positively influence TA level during a storage time longer than $48 \mathrm{~h}$, while in the case of TPP and ORAC, their values progressively enhanced up to $120 \mathrm{~h}$ of storage, in particular when samples were irradiated for $1 \mathrm{~min}$ and stored at $4{ }^{\circ} \mathrm{C}$. This means that a fresh product with enhanced quality value can be offered to consumers within the typical conditions of market commercialization.

Since polyphenol and anthocyanin profile is a varietal characteristic, further researches are in progress to extend the aforementioned findings to other cultivars for proposing such phytochemical-enriched grapes to be served as fresh products or used as raw material for functional foods and supplements and would act as a complementary or synergistic strategy to human nutrition programs and policy for enhancing the consumption of phytochemicals.

\section{Acknowledgements}

This study was supported by grant from Apulia Region (PO FESR-FSE 2007-2013-Project TEGUVA cod.61/09), the Italian Ministry of University and Research-MIUR (PON "R\&C"-2007-2013-Project ONEVcod.00134/2011).

\section{References}

Alothman, M., Bhat, R., \& Karim, A. A. (2009). UV radiation-induced changes of antioxidant capacity of fresh-cut tropical fruits. Innovative Food Science and Emerging Technologies, 10, 512-516. http://dx.doi.org/10.1016/j.ifset.2009.03.004

Amarowicz, R., Carle, R., Dongowski, G., Durazzo, A., Galensa, R., Kammerer, D., .. Piskula, M. K. (2009). Influence of postharvest processing and storage on the content of phenolic acids and flavonoids in foods. Molecular Nutrition and Food Research, 53, S151-S183. http://dx.doi.org/10.1002/mnfr.200700486

Cantos, E., Espin, J. C., \& Tomas-Barberan, F. A. (2001). Postharvest induction modeling method using UV irradiation pulses for obtaining resveratrol-enriched table grapes: a new "Functional" fruit. Journal of 
Agricultural and Food Chemistry, 49, 5052-5058. http://dx.doi.org/10.1021/jf010366a

Cook, N. C., \& Samman, S. (1996). Flavonoids-Chemistry, metabolism, cardioprotective effects, and dietary $\begin{array}{lllll}\text { sources. The Journal of Nutritional Biochemistry, } & \text { 7, }\end{array}$ http://dx.doi.org/10.1016/S0955-2863(95)00168-9

Cordenunsi, B. R., Genovese, M. I., do Nascimento, J. R., Hassimotto, N. M., dos Santos, R. J., \& Lajolo, F. M. (2005). Effects of temperature on the chemical composition and antioxidant activity of three strawberry cultivars. Food Chemistry, 91, 113-121. http://dx.doi.org/10.1016/j.foodchem.2004.05.054

Crupi, P., Coletta, A., Milella, R. A., Perniola, R., Gasparro, M., Genghi, R., \& Antonacci, D. (2012). HPLC-DAD-ESI-MS Analysis of Flavonoid Compounds in 5 Seedless Table Grapes Grown in Apulian Region. Journal of Food Science, 77, C174-C181. http://dx.doi.org/10.1111/j.1750-3841.2011.02555.x

Dong, Y., Mitra, D., Kootstra, A., Lister, C., \& Lancaster, J. (1995). Postharvest stimulation of skin color in "Royal Gala" apple. Journal of the Amererican Society for Horticultural Science, 120, 95-100.

Glories, Y. (1998). Les compos'es ph'enoliques. In P. Ribereau-Gayon Dunod (Ed.) La notion de maturation ph'enolique, in Trait'e d'Oenologie, Vol. II, Chimie du Vin Stabilisation et Traitements (pp. 220-221). Paris.

Goldmann, I. L., Kader, A. A., \& Heintz, C. (1999). Influence of production, handling, and storage on $\begin{array}{lllll}\text { phytonutrient content of } & \text { Foods. Nutrition Reviews, } & \text { 57, 46-52. }\end{array}$ http://dx.doi.org/10.1111/j.1753-4887.1999.tb01807.x

Goncalves, B., Landbo, A.K., Knudsen, D., \& Silva, A. P. (2004). Effect of ripeness and postharvest storage on the phenolic profiles of cherries (Prunus avium L.). Journal of Agricultural and Food Chemistry, 52, 523-530. http://dx.doi.org/10.1021/jf030595s

Huyskens-Keil, S., \& Schreiner, M. (2004). Quality dynamics and quality assurance of fresh fruit and vegetables in pre- and postharvest. In R. Dris \& S. Jain (Eds.) Production Practices and Quality Assessment of Food Crops (pp. 401-449). Kluwer Academic Publishers, Dordrecht. http://dx.doi.org/10.1007/1-4020-2534-3_15

Kalt, W., Forney, C. F., Martin, A., \& Prior, R. L. (1999). Antioxidant capacity, vitamin C, phenolics, and anthocyanins after fresh storage of small fruit. Journal of Agricultural and Food Chemistry, 47, 4638-4644. http://dx.doi.org/10.1021/jf990266t

Kataoka, I., \& Beppu, K. (2004). UV irradiance increases development of red skin color and anthocyanins in 'Hakuho' peach. Horticultural Science, 39, 1234-1237.

Lattanzio, V. (2003). Bioactive polyphenols: Their role in quality and storability of fruit and vegetables. Journal of Applied Botany, 77, 128-146.

Li, X. D., Wu, B. H., Wang, L. J., Zheng, X. B., Yan, S. T., \& Li, S. H. (2009). Changes in trans-resveratrol and other phenolic compounds in grape skin and seeds under low temperature storage after post-hatvest UV-irradiation. The Journal of Horticultural Science and Biotechnology, 84, 113-118.

López-Rubira, A., Conesa, A., Allende, A., \& Artés, F. (2005). Shelf life and overall quality of minimally processed pomegranate arils modified atmosphere packaged and treated with UV-C. Postharvest Biology and Technology, 37, 174-185. http://dx.doi.org/10.1016/j.postharvbio.2005.04.003

Meyers, K. J., Watkins, C. B., Pritts, M. P., \& Liu, R. H. (2003). Antioxidant and antiproliferative activities of strawberries. Journal of Agricultural and Food Chemistry, 51, 6887-6892. http://dx.doi.org/10.1021/jf034506n

Milella, R. A., Antonacci, D., Crupi, P., Incampo, F., Carrieri, C., Semeraro, N., \& Colucci, M. (2012). Skin extracts from 2 Italian table grapes (Italia and Palieri) inhibit tissue factor expression by human blood mononuclear cells. Journal of Food Science, 77(8), H154-H159. http://dx.doi.org/10.1111/j.1750-3841.2012.02818.x

Morelli, D., Antonacci, D., Perniola, R., Crupi, P., Milella, R. A., Coletta, A., \& Caputo, A. R. (2008). The water decrease as a factor conditioning the table grape quality: the Redglobe variety example. In XXXI International O. I. V. Congress Proceedings - Verona (Italy), June 15-20th.

Nunes, M. C. N., Brecht, J. K., Morais, A. M., \& Sargent, S. A. (2006). Physicochemical changes during strawberry development in the field compared to those that occur in harvested fruit during storage. Journal of the Science of Food and Agriculture, 86, 180-190. http://dx.doi.org/10.1002/jsfa.2314

Olsson, M. E., Ekvall, J., Gustavsson, K. E., \& Nilsson, J. (2004). Antioxidants, low molecular weight 
carbohydrates, and total antioxidant capacity in strawberries (Fragariaxananassa): Effects of cultivar, ripening, and storage. Journal of Agricultural and Food Chemistry, 52, 2490-2498. http://dx.doi.org/10.1021/jf030461e

Ou, B., Hampsch-Woodill, M., \& Prior, R. L. (2001). Development and validation of an improved oxygen radical absorbance capacity assay using fluorescein as the fluorescent probe. Journal of Agricultural and Food Chemistry, 49, 4619-4626. http://dx.doi.org/10.1021/jf010586o

Oufedjikh, H., Mahrouz, M., Amiot, M. J., \& Lacroix, M. (2000). Effect of gamma irradiation on phenolic compounds and phenylalanineammonia-lyase activity during storage in relation to peel injury from peel of Citrus clementina Hort. Ex. Tanaka. Journal of Agricultural and Food Chemistry, 48, 559-565. http://dx.doi.org/10.1021/jf9902402

Pan, J., Vicente, A. R., Martinez, G. A., Chaves, A. R., \& Civello, P. M. (2004). Combined use of UV-C irradiation and heat treatment to improve postharvest life of strawberry fruit. Journal of the Science of Food and Agriculture, 84, 1831-1838. http://dx.doi.org/10.1002/jsfa.1894

Plustoka, W. E., Michalczyk, D. J., \& Gorecki, R. J. (2005). Control of phenylalanine ammonia-lyase gene promoters from pea by UV radiation. ACTA Physiologiae Plantarum, 27, 229-236. http://dx.doi.org/10.1007/s11738-005-0027-1

Schreiner, M., \& Huyskens-Keil, S. (2006). Phytochemicals in Fruit and Vegetables: health promotion and postharvest elicitors. Critical Reviews in Plant Science, 25, 267-278. http://dx.doi.org/10.1080/07352680600671661

Shin, Y., Liu, R. H., Nock, J. F., Holliday, D., \& Watkins, C. B. (2007). Temperature and relative humidity effects on quality, total ascorbic acid, phenolics and flavonoid concentrations, and antioxidant activity of $\begin{array}{llllll}\text { strawberry. Postharvest Biology and } & \text { Technology, } & \text { 45, } & \text { 359-357. }\end{array}$ http://dx.doi.org/10.1016/j.postharvbio.2007.03.007

Sun, J., Chu, Y. F., Wu, X. Z., \& Liu, R. H. (2002). Antioxidant and antiproliferative activities of common fruits. Journal of Agricultural and Food Chemistry, 50, 7449-7454. http://dx.doi.org/10.1021/jf0207530

Takayanagi, T., Okuda, T., Mine, Y., \& Yokotsuka, K. (2004). Induction of resveratrol biosynthesis in skins of three grape cultivars by ultraviolet irradiation. Journal of the Japanese Society for Horticultural Science, 73, 193-199. http://dx.doi.org/10.2503/jjshs. 73.193

Teissedre, P. L., Waterhouse, A. L., Walzem, R. L., German, J. B., Frankel, E. N., Ebeler, S. E. \& Clifford, A. J. (1996). Phenolic compounds of grape and wine and health. Bulletin de L'OIV, 69, 251-277.

Terry, L. A., \& Joyce, D. C. (2004). Elicitors of induced disease resistance in postharvest horticultural crops: A

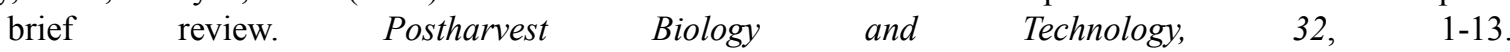
http://dx.doi.org/10.1016/j.postharvbio.2003.09.016

Tomas-Barberan, F., \& Espin, J. (2001). Phenolic compounds and related enzymes as determinants of quality in fruit and vegetables. Journal of the Science of Food and Agriculture, 81, 853-876. htpp://dx.doi.org/10.1002/jsfa.885

Wang, C. Y., Chen, C., \& Wang, S. Y. (2009). Changes of flavonoid content and antioxidant capacity in blueberries after illumination with UV-C. Food Chemistry, 117, 426-431. http://dx.doi.org/10.1016/j.foodchem.2009.04.037

Wang, H., Cao, G. H., \& Prior, R. L. (1997). Oxygen radical absorbing capacity of anthocyanins. Journal of Agricultural and Food Chemistry, 45, 304-309. http://dx.doi.org/10.1021/jf960421t 


\section{Supporting Information}

Table S1. Schematic representation of the full factorial experimental design $(2 \times 4 \times 4=32$ unique runs). Grape samples were exposed to UV-C irradiation during 1,3 , and $5 \min \left(0.8,2.4\right.$, and $4.1 \mathrm{KJ} \mathrm{m}^{-2}$, respectively) followed by temperature (room temperature vs $4{ }^{\circ} \mathrm{C}$ ) and time $(0,24,48$, and $120 \mathrm{~h}$ ) modification. Factor A: storage temperature; Factor B: storage time; Factor C: UV-C treatment

\begin{tabular}{|c|c|c|c|c|c|}
\hline Factor A & Factor B & Facto & & & \\
\hline & & 0 & 1 & 2 & 3 \\
\hline 0 & 0 & 000 & 001 & 002 & 003 \\
\hline 0 & 1 & 010 & 011 & 012 & 013 \\
\hline 0 & 2 & 020 & 021 & 022 & 023 \\
\hline 0 & 3 & 030 & 031 & 032 & 033 \\
\hline 1 & 0 & 100 & 101 & 102 & 103 \\
\hline 1 & 1 & 110 & 111 & 112 & 113 \\
\hline 1 & 2 & 120 & 121 & 122 & 123 \\
\hline 1 & 3 & 130 & 131 & 132 & 133 \\
\hline
\end{tabular}

Table S2. Regression parameters of the equations representing the postharvest total polyphenols (TPP), anthocyans (TA), and oxygen radical antioxidant capacity (ORAC) in Redglobe (Vitis vinifera L.) table grape harvested in $2011^{a}$

\begin{tabular}{lccc}
\hline & TPP & TA & ORAC \\
\hline main effects & & & \\
UV-C treatment $\left(\mathrm{a}_{1}\right)$ & -0.003 & 0.07 & 0.08 \\
Storage time $\left(\mathrm{a}_{2}\right)$ & $\mathbf{0 . 0 0 4}$ & $\mathbf{0 . 0 3 6}$ & $\mathbf{0 . 0 1 5}$ \\
Storage temperature $\left(\mathrm{a}_{3}\right)$ & $\mathbf{0 . 0 0 2}$ & 0.00054 & $\mathbf{- 0 . 0 1 9}$ \\
& & & \\
interactions & & & \\
Storage time x UV-C treatment $\left(\mathrm{a}_{12}\right)$ & 0.000066 & $\mathbf{- 3 . 2 E - 0 5}$ & 0.00043 \\
Storage temperature x UV-C treatment $\left(\mathrm{a}_{13}\right)$ & -0.0011 & 0.0013 & -0.00049 \\
Storage time x Storage temperature $\left(\mathrm{a}_{23}\right)$ & $\mathbf{0 . 0 0 0 0 7 6}$ & 0.000021 & $\mathbf{- 0 . 0 0 0 4 2}$ \\
& & & \\
quadratic terms & & & \\
(UV-C treatment $)^{2}\left(\mathrm{a}_{11}\right)$ & 0.003 & $\mathbf{- 0 . 0 1 2}$ & -0.021 \\
(Storage time $^{2}\left(\mathrm{a}_{22}\right)$ & -0.000015 & $\mathbf{- 0 . 0 0 0 2}$ & -0.000029 \\
(Storage temperature $^{2}\left(\mathrm{a}_{33}\right)$ & 0.00001 & -0.0002 & 0.000022 \\
intercept $\left(\mathrm{a}_{0}\right)$ & $\mathbf{0 . 9 5}$ & $\mathbf{0 . 9 2}$ & $\mathbf{0 . 9 3}$ \\
\hline
\end{tabular}

${ }^{a}$ The corresponding terms in the model equations are given between brackets. Significant terms are in bold.

\section{Copyrights}

Copyright for this article is retained by the author(s), with first publication rights granted to the journal.

This is an open-access article distributed under the terms and conditions of the Creative Commons Attribution license (http://creativecommons.org/licenses/by/3.0/). 